\title{
STONES IN THE SOUTH \\ Decoding Bronze Age Ritual Practices on Gotland
}

Helene Martinsson-Wallin ${ }^{1}$ \& Joakim Wehlin ${ }^{2}$

\footnotetext{
${ }^{1}$ Uppsala University

Campus Gotland

62167 Visby, Sweden

helene.martinsson-wallin@arkeologi.uu.se

2 Dalarna Museum

Box 22, 79121 Falun, Sweden

joakim.wehlin@dalarnasmuseum.se
}

In this paper, we discuss the ritual practices and ritualization in the Bronze Age society on Gotland based on archaeological investigations of cairn milieus and stone ship contexts. We explore whether erected stones and demarcations on the south to south-west side of the Bronze Age cairns are the norm and whether this phenomenon occurred during the Bronze Age. We also discuss whether our archaeological research can support long-term use of cairn milieus for ritual purposes.

Keywords: Gotland, Bronze Age, monument, cairn, ship setting, south stones 


\section{INTRODUCTION}

Through empirical studies of Bronze Age cairns and stone ship settings on Gotland, we want to explore the practices tied to these materialized expressions. Bronze Age cairns and ship settings on Gotland are linked to burial practices (Hansson 1927; Stenberger I94I, I942; MartinssonWallin 20I0; Wehlin 20I3). Thus, we suggest that such observed practices can say something about rituals in connection with the burial act. Our aim is to decode these rituals or ritualized actions, which are of importance in the discussion of group dynamics as well as expressions of individual power relations present in the Gotlandic Bronze Age society during the time frame $c$. $1700-500 \mathrm{BC}$. To make reconstructions of the past we need to date these stone structures and deconstruct their contexts. In a recent study on the role of archaeology in ritual studies Berggren and Nilsson Stutz (20I0:80), suggest that: 'If we can establish a core of practices for the burial of the dead, a norm, we could assume that this norm, through the structure of significance, would be related to other norms in society.' We agree with them that archaeology can contribute to the development of ritual theory by studying the practices (Berggren \& Nilsson Stutz 20IO:I7I).

The initial focus of our research is directed to what people in the past were doing and not on the meaning of the action. We base this approach on Bourdieu's theory of practice (1977). Bell's classical study Ritual Theory, Ritual Practice (I992), where she coins the term ritualization, is also an inspiration. This concept, according to her, means strategic ways of acting where the specific ritual practice that is privileged, significant, and powerful is embedded (Bell 1992:7). She discusses how rituals are part of a structuration process and not expressions of specific meanings. We agree that ritual practices per se can be repeated unconscious bodily doing/action (habitus) and embedded within the social structure of society, but we also aim to understand meanings of the ritual through analogies and comparative studies (Kaliff \& Østigård 20I3). Here we address the implications of rapid changes, varieties and additions of the phenomenon tied to ritual activities. These actions cannot just be explained as the reproduction of the ritual becoming flawed, declining and being forgotten. We suggest that such changes, especially if they are rapid and revolutionary, are products of conscious actions, since they consequently can be observed by sudden changed practices. The change of meaning of things could thereby be possible to detect through a practice perspective in combination with the use of analogies and comparative research. The starting point of our research is thus to tease apart various built and natural features tied to the material expressions in the 
form of cairns and adjacent structures as well as stone ship settings to investigate their temporal and spatial relationships. New empirical data with the dating of various activities tied to Bronze Age cairns and indications of the long-term use of cairn milieus show that we need a new framework for interpretation of ritual practices. We place a particular focus on the erected stones, generally found on the south-west side close to the cairns, known as 'south stones', but also discuss the placing and relationship of stone ships, adjacent platforms and stone settings. Here we widen the concept of south stones, that was coined by Nylén (I959, I993), i.e. an upright monolith on the south side of the cairn, to yield a broader concept, south stone structures, which includes one or more uprights and adjacent platforms and stone setting on the south side of the cairns.

\section{BRONZE AGE CAIRNS AND STONES IN THE SOUTH}

There are well over a thousand Bronze Age cairns registered on Gotland, and around two hundred of these exceed 20 metres in diameter, and have a height of 2 metres or above. The cairns have a spatial distribution all over the island, usually located close to the Bronze Age seashore (Figure I). Often, they are made up of natural granite stones 20-50 centimetres in size. A few structures that have been excavated or partially destroyed show an internal dry stone wall of limestone slabs stacked on top of each other that surrounds stone cists with human burials (Stenberger I94I, 1942; Franzén 20I2) (Figure 2).

The majority of the cairns are thought to have been constructed in the Early Bronze Age (c. I700-II00 BC) as burial sites. Archaeological investigations on Gotland and elsewhere in the Scandinavian area show that such sites have complex biographies (Stenberger I94I, I942; Rydh I967, I968; Lindquist 1976, I979; Kristiansen I998; Gansum 2002, 2004; Holst et al. 2004; Kristiansen \& Larsson 2005; Goldhahn 2006, 20I3; König 2007; Franzén 20I2). In south Scandinavia, the burial structures during the Early Bronze Age are mainly in the form of mounds made up of soil, peat and stones (Holst et al. 2004). The internal structure and outline, as well as dates of human skeletal remains and finds in investigated cairns on Gotland, show that some of these sites initially were constructed as stone cists surrounded by concentric stone walls during the Late Neolithic (c. 2300-I700 BC). Some continued to be used in the Early Bronze Age (for example see Rydh I967, I968; Burenhult 1986). Some cairns on Gotland also continued to be used as burial grounds during the Late Bronze Age (c. I100-500 BC) 
since they feature secondary deposits of cremations of human skeletal remains among the stone fill (Stenberger 1942; Burenhult 1986; Wehlin \& Schönbäck 20I3). Stone ship settings are additional burial structures in the Late Bronze Age (Wehlin 2013). Thus, archaeological investigations indicate that the burial practice tied to the cairn structures very likely started as inhumation burials placed in stone cists surrounded

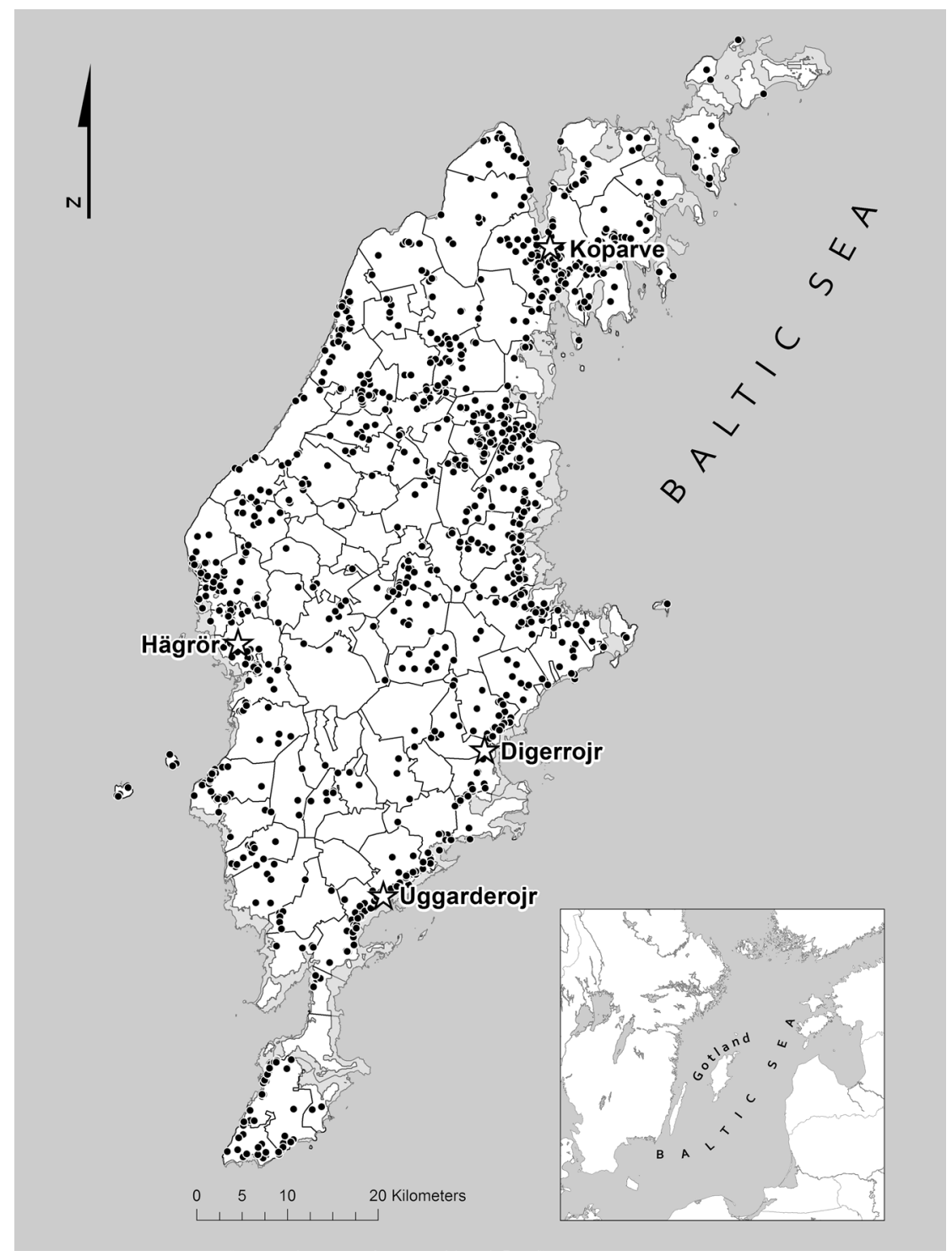

Figure I. Gotland island with all stone cairns over Io metres in diameter. Case studies marked. Illustration: Anton Uvelius. 


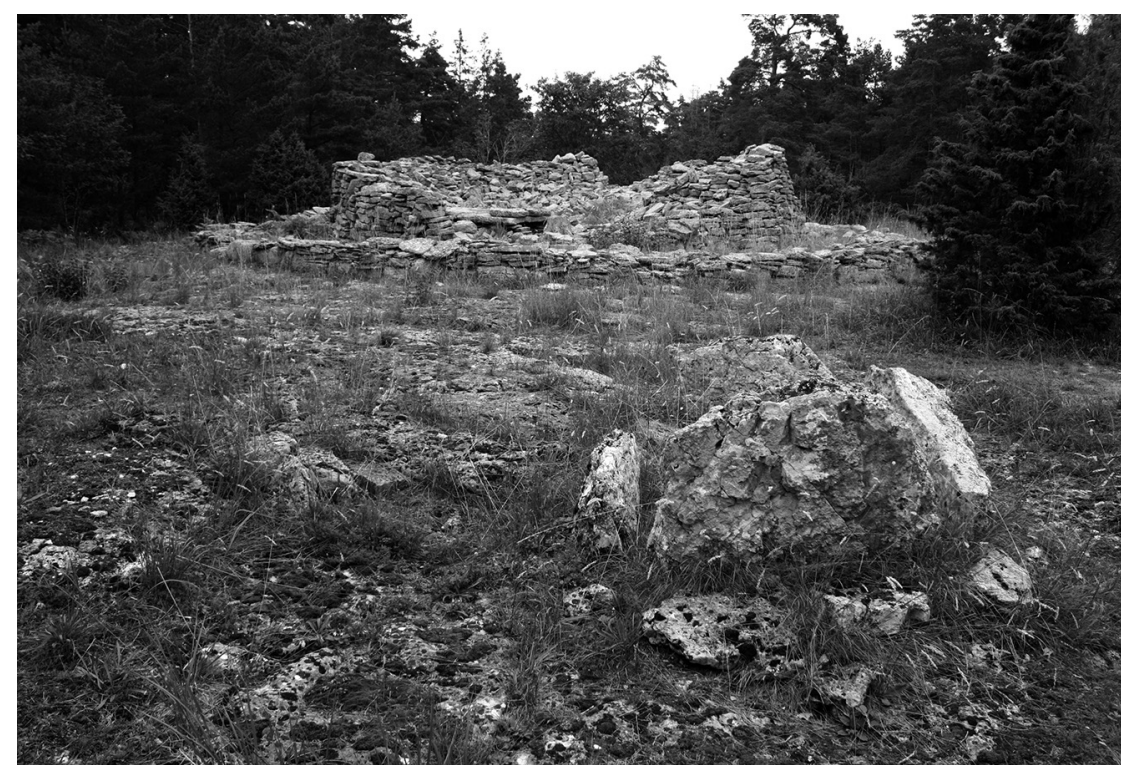

Figure 2. One of the two internal dry stone walls of limestone slabs at the Koparve cairn. South of the cairn there are four larger limestone slabs. Photo: Joakim Wehlin.

with concentric stone walls in the Late Neolithic. Some of them were constructed or continued to be used in the Early Bronze Age, possibly as 'open' monuments. Compare with the Bredarör cairn in Kivik (Goldhahn 2006:I77-I8I). There are also changes in grave goods, with the flint dagger seemingly the norm in the Late Neolithic. In the Early Bronze Age bronze daggers and swords replaced the flint artefacts, i.e. the same type of grave goods occurred but in different material. In the Bronze Age period III (c. I300-I I00) the grave goods change, jewellery along with double-buttons and so-called razors and tweezers become more common and fewer weapons were deposited (Baudou I960; Hyenstrand I968; Aner \& Kersten I973-; Oldeberg I974-76). Also, the interior outline of the stone cists of the Gotland cairns seems to change from a central position in the Late Neolithic and Early Bronze Age to a south to south-west position (Nylén I993). This change might show a new ritual practice that placed the importance of a south location.

The major change in the burial practice occurred when the ship settings with cremation burials appeared in the transition between Early and Late Bronze Age. Below we discuss the changes in burial practices and the relationship to the south stone structures through some case studies on Gotland. The standing stone phenomenon is prevalent in connection with the cairns, usually as single monoliths or sometimes two or more in groups, where some show a ship-like formation. South 
or south-south-west side of the cairns is the most common location of these standing stones. The term south stones was coined by the Gotlandbased archaeologist Erik Nylén in the I950s when he initiated a research programme on Bronze and Iron Age remains (Nylén 1959, 1993). He was of the opinion that these standing stones were significant in the burial practice as places of sacrifice to the dead in the Bronze Age and Early Iron Age. He noted that in the Bronze Age the south stones were of granite, usually of a large size, and in the Early Iron Age they were of limestone and smaller in size. Nylén (I993) suggests that this practice is found on Gotland and not recorded on the Swedish mainland. The practice of south stones, and ritual practice associated with the south location, might have a connection to the typical Gotlandic ship settings from the Late Bronze Age. Nylén further suggests that the Hügelgräber culture on the continent of Europe and Polish relations were the source of inspiration for this type of structure (Nylén 1993:I27).

Nylén never launched a coherent programme for investigating the Bronze Age monuments. Around 50 years later we initiated a research project with the aim of investigating his observations further to understand Bronze Age socio-cultural dynamics on Gotland. Our project investigates issues relating to the dynamics of monuments and ritual practice in a long-term perspective (Martinsson-Wallin 20Io; Wehlin 20I3). We suggest that the burial practices and the phenomenon of creating cairns to cover the dead, to erect the standing stones and platforms/ stone settings south-south-west of the cairns as well as adding a new type of burial structure, the ship setting, have ritual connotations. The built landscape inscribed on the physical landscape forms milieus for certain rituals and sacrifices during the time frame that we archaeologists label the Bronze Age. One of our research questions explored in this paper is the temporal status of the south stone structures (including monoliths, platforms and stone settings) in relation to the cairns and the ship settings.

\section{CASE STUDIES: UGGARDEROJR, DIGERROJR, HÄGRÖR AND KOPARVE CAIRNS}

In the Swedish archaeological sites and monuments database (FMIS) there is information on more than thousand cairns with a size over Io metres in diameter found on Gotland that are defined as belonging to the Bronze Age (Figure I). However, the archaeological remains called 'cairns' are ambiguous, since cairns of smaller dimensions were also made during the Iron Age. Large-scale structures that are over 20 metres 
in size and exceed a height of 2 metres have been confirmed by archaeological excavations as belonging to the Bronze Age (Stenberger I94I, 1942; Rydh 1967; Burenhult 1986; Franzén 20I2).

In the national database around $25 \%$ of the Bronze Age cairns found on Gotland that are over 20 metres are recorded as having south stones (generally meaning erected monoliths south of the cairn) connected to them. When we have assessed the data by site visits to some of the cairns that did not have this type of feature recorded during the previous survey, all of the visited sites displayed erected stones to the south or south-west. It is very likely that most of the monuments had such structures tied to them in the past. Later activities have probably removed some of these stones, or they have fallen and been overgrown and thus overlooked by the surveyor. A complete re-survey of all the known cairns on Gotland and their close environment is a task still to be carried out. So far we can say that the national database (FMIS), site visits by us, and the observations by Nylén (1958, 1993) show that south stone structures and platforms/stone settings to the south have a relationship to the cairns and vice versa. Our investigation suggests that cairns and south stone structures are connected. This practice shows the norm of a relationship between the cairns, the standing stones and the south-south-west direction, but it is not certain that these features are contemporary with each other. The spatial distribution of the cairns indicates that structures are often placed at the Bronze Age seashore. There is a normative relationship between the cairns and sea/water. We suggest that the relationships mentioned above form cairn milieus that are nodes in a cognitive landscape as places for various rituals. With this data at hand, our suggestion is that these milieus are complex ritual places tied to death and genealogies that go beyond previous interpretations of cairns as merely representing burial sites.

In our research programme we have so far carried out investigations at four sites of large-scale Bronze Age cairn environments. Our investigations at Uggarderojr, Hägrör and Digerrojr cairns focused on exploring the milieu outside the cairn perimeter, the temporal status of south stone structures and platforms/stone settings in a southerly location (Martinsson-Wallin \& Wehlin 20IO, 20II; Martinsson-Wallin 20I4). At Koparve we have focused on the milieu inside the cairn perimeter. Stenberger initiated excavations at Koparve cairn in I94I, followed by investigations by Arwidsson 1948 and Hallström 1966 (Stenberger 1942; Arwidsson 1949; Lindquist 1979). The skeletal remains have been reanalysed on the initiative of Martinsson-Wallin (Hongslo-Vala 20I0; Foglemark 20II). We have also made comparative analyses using data from a few other excavated Bronze Age burial cairns which have been 
removed due to the construction of a road or affected by limestone quarries (Stenberger 194I, 1942; Lindquist 1979; Burenhult 1986; Wehlin \& Schönbäck 20I2).

\section{UGGARDEROJR}

The investigation at Uggarderojr, which is the largest stone cairn on Gotland, was carried out during five weeks in 2009. This structure is roughly 50 metres in diameter and 7 metres high (Figure 3 ) and located on the south-east coast of Gotland. The aim was to investigate two low stone mounds on the south-west side of the mound and also excavate next to a large kerbstone on the south side of the cairn. It is likely that two smaller fallen stones in the vicinity could be 'traditional' south stone markers, but we focused our excavations on the rounded stone setting, fire-cracked heap and large kerbstone with cup marks, all situated south and south-west of the mound. Our aim was also to understand this monument in relationship to the Bronze Age landscape. Today it is situated I.5 kilometres from the shore, but the shoreline displacement has had major effects on altering the landscape since the Bronze Age. The area is called Uggarderum, meaning 'the room/space of the remote farm'. This area is a special place with nodes of at least seven

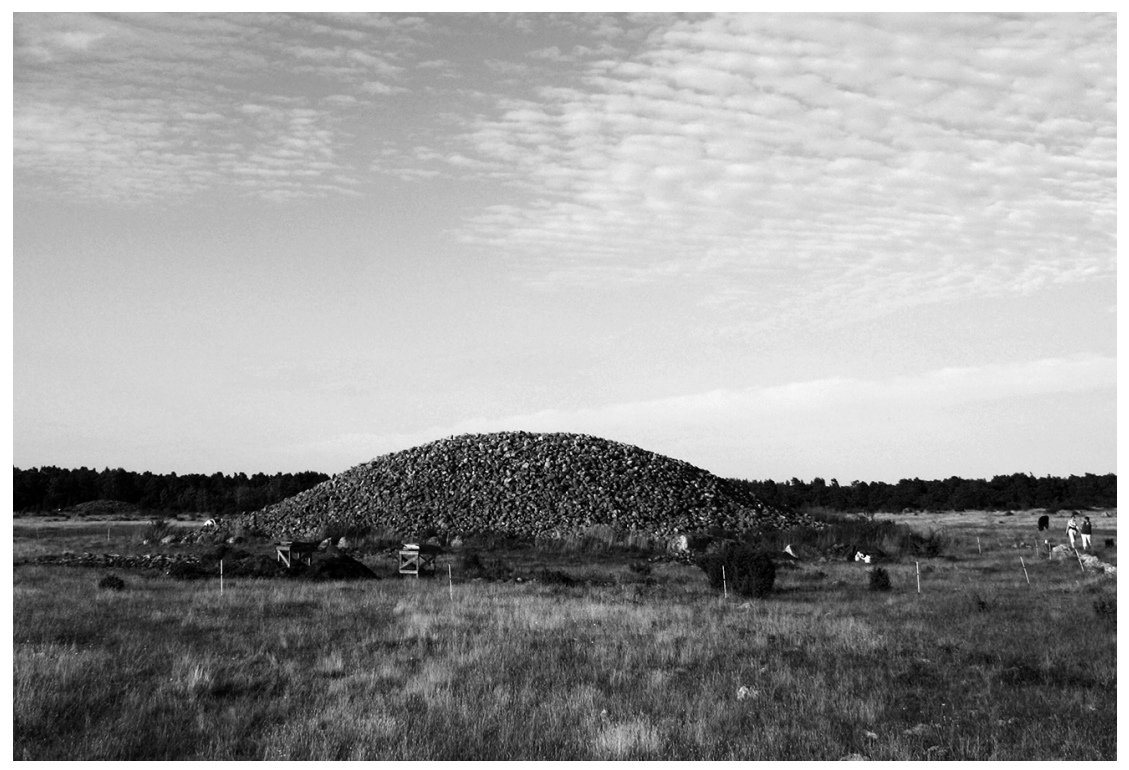

Figure 3. The largest Bronze Age cairns on Gotland, Uggarderojr, Rone parish. Photo: Joakim Wehlin. 


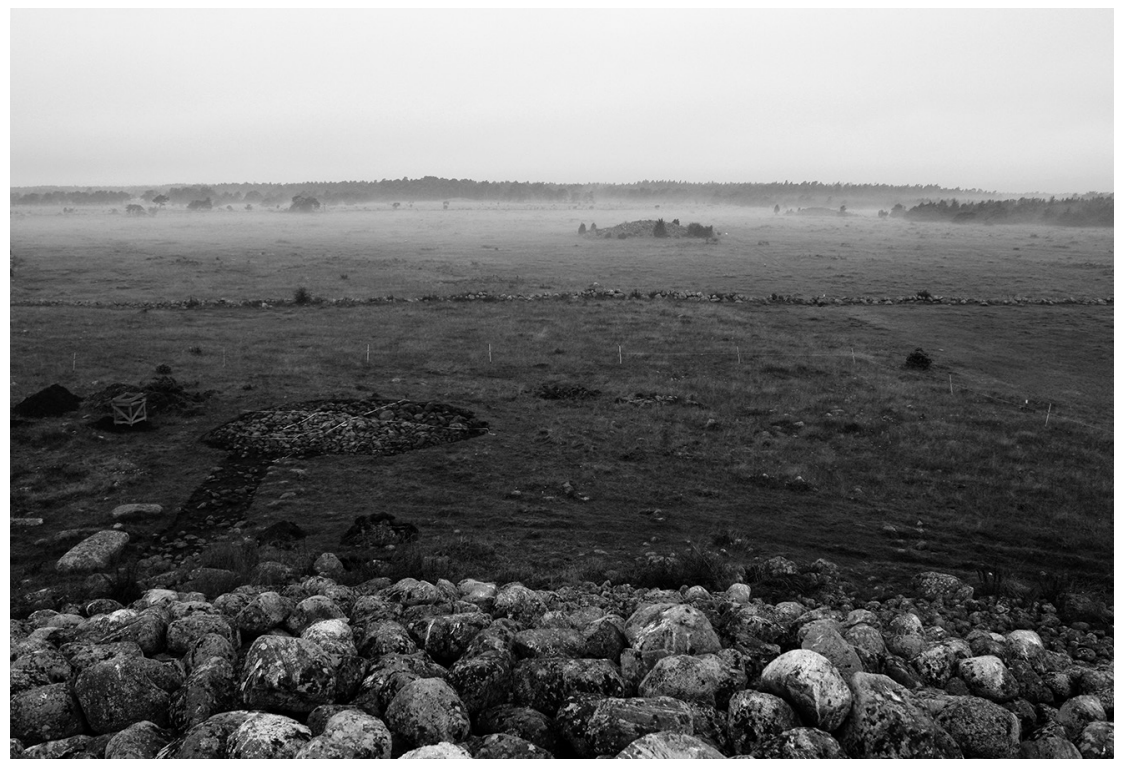

Figure 4. Stone structures south-west of Uggarderojr during excavation 2009. The photo was taken from the top of the large cairn to show the surrounding landscape, Uggarderummet. Photo: Joakim Wehlin.

large Bronze Age cairns that all exceed 20 metres in diameter within an area of Ioo-500 metres around the large Uggarderojr cairn. The closest Bronze Age settlement is situated at Vinarve about 2 kilometres inland to the west of Uggarderum (Lindquist 1974).

The rounded stone setting located some ro metres south-west of the cairn (Figure 4), was 9 metres large and around 0.5 metre high and shows at least three phases of utilization. In the centre of the bottom layer was a pit found that probably is a posthole. Selected stone material made up this platform-like stone setting. The edges of the setting were made up of sandstone slabs (compare e.g. with Sagaholm, Goldhahn 2006:I84-190), and there were several stones with cup marks and probably selected stones that featured special colours and natural pits. We also found flint flaking distributed over the surface of the initial stone setting. This phase has been radiocarbon dated to $c$. I450-I2IO BC (LuS-8682 Cal. 2 sigma) (see Figure 5). In the next phase, the pit in the middle was covered with stones. Among the stones cremated bones were found, a few of them of human origin. A large flat stone sealed most of the cremated bones. They were dated to c. 900-790 BC (Ua4II84 Cal. 2 sigma) and c. 920-8Io BC (Ua-4II85 Cal. 2 sigma) (see Figure 5). It is important, however, to keep in mind that the dating of burnt bones is problematic, not least regarding what temperature they 


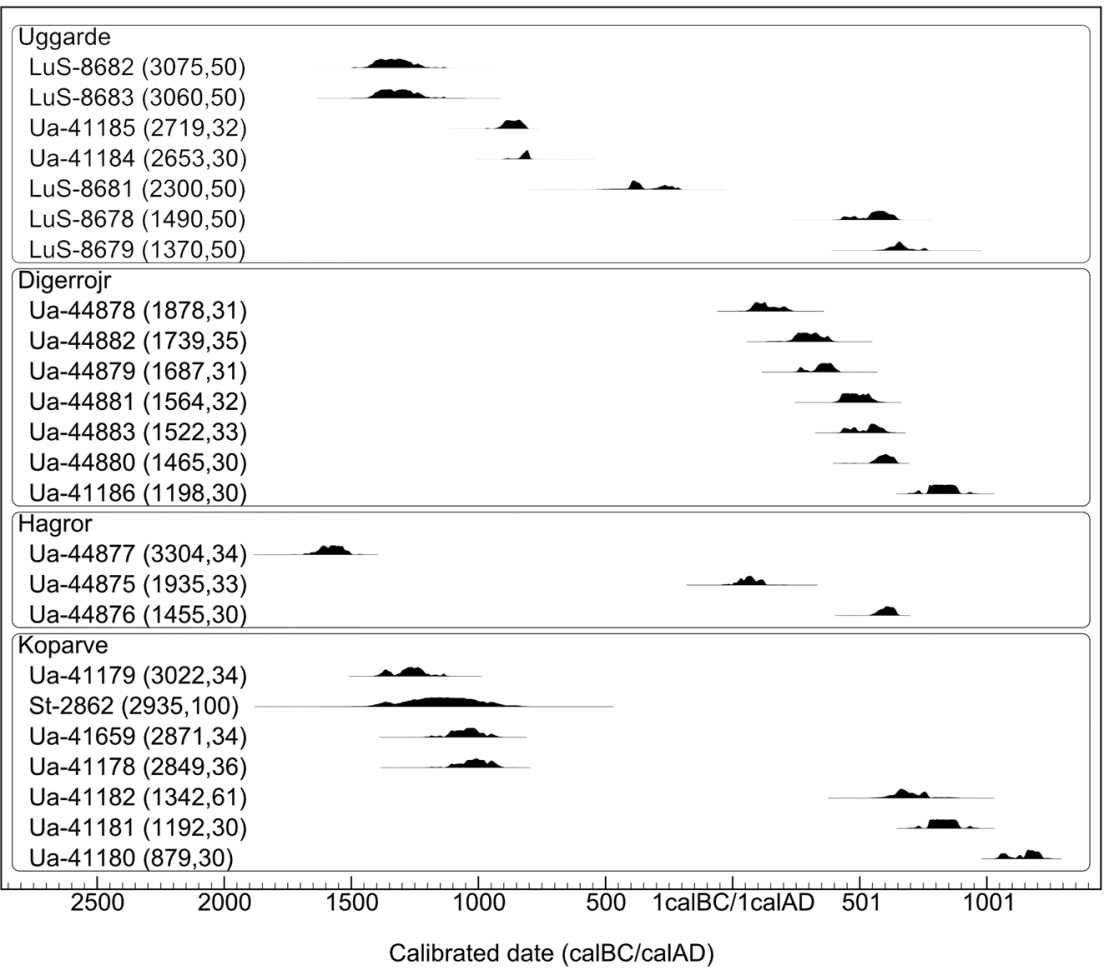

Figure 5. The result of the ${ }_{14} \mathrm{C}$ analysis made at the four case study sites. Calibration in OxCal 4.2 (Bronk Ramsey 2009) with the calibration curve IntCalı3 (Reimer et al. 20I3).

were burned at (Wehlin 2013:20). In the third phase the structure was added on with stones and among the stones in the middle were unburnt bones of sheep, mainly from head and teeth. The bones showed a date of c. 490-200 BC (LuS-868I Cal. 2 sigma) (see Figure 5).

The stone setting to the east of the former showed to be a $2 \times 2$ metre large heap of fire-cracked stones. A human hand bone (pisiform), a dog's heel bone (talus), a tooth and part of a shoulder blade (scapula), a hare bone $(u \ln a)$, a part of pig jaw and a toe bone from cattle were among the sparse finds (Svensson 20I0). A few pieces of plain pottery were also found. A radiocarbon sample from this context was dated to $c$. I430I I30 BC (LuS-8683 Cal. 2 sigma) (see Figure 5). This date overlaps with the earliest phase of the larger stone setting.

Excavations at two kerbstones on the south and south-west side of the cairn also gave interesting results. At the base of the south kerbstone, traces of fires and foot bones from cattle were deposited but they were not affected by fire. The date of one of bone was $c$. AD 580-770 (LuS-8679 Cal. 2 sigma) (see Figure 5) and at another kerbstone there 
were fragmented cattle horns, dated to $c$. AD 430-650 (LuS-8678 Cal. 2 sigma) (see Figure 5).

It is very likely that some smaller fallen stones situated close to the kerbstone in the south location may be a 'traditional' south stone structure, but unfortunately we did not have time to investigate during the excavation.

The results of our investigations of the examined features found to the south-south-west of Uggarderojr show ritual practices that we suggest are contemporary with the initial burial in the cairn during the Early to Middle Bronze Age. These rituals included fires and fire-cracked stones, flint flaking, and probably the making of cup marks. The dated activities show that this site was a node for ritual practices for about 2000 years.

\section{DIGERROJR}

To compare our findings at Uggarderojr cairn we made an additional investigation at the large cairn of Digerrojr (Martinsson-Wallin \& Wehlin 20II; Martinsson-Wallin 20II) also situated on the east coast of Gotland but some 40 kilometres to the north of Uggarderojr. Digerrojr is around 40 metres in diameter and 5 metres high. It has a 2 metre deep crater in the middle. Five standing stones situated on the south side of the

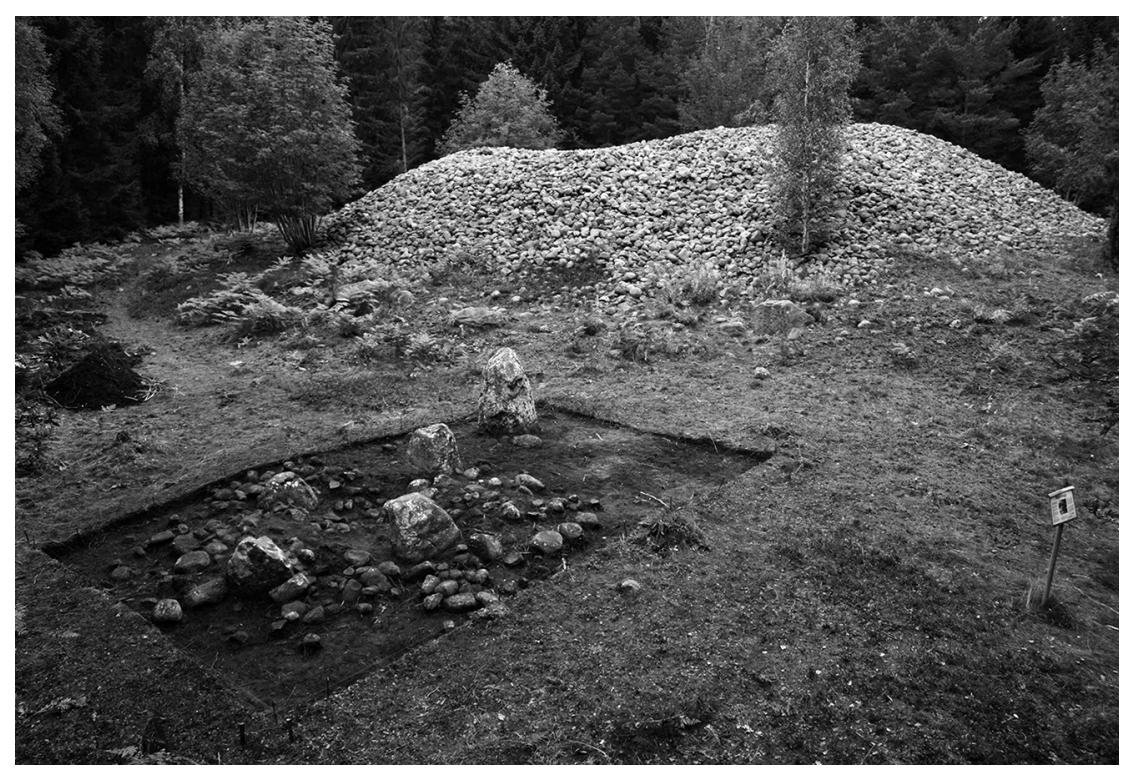

Figure 6. Digerrojr and the south structures during excavation 20I0. Photo: Joakim Wehlin. 
cairn form a rhombic shape surrounded by a stone filling. This formation could have functioned as a ship-setting-like structure and included a 'traditional' south stone (as defined by Nylén 1959) at the same time (Figure 6) (Wehlin 2013:70). Our excavation showed that the erected stones were fire-cracked at the bases and the soil below them was burnt and contained ash, but no charcoal. The absence of charcoal around the stones might indicate that after firing the surface had been cleaned. However, three dated charcoal samples in the vicinity below the stone setting showed Iron Age dates. The earliest date was $c$. AD 70-225 (Ua-44878 Cal. 2 sigma) and the other two samples $c$. AD 260-420 (Ua-44879 Cal. 2 sigma) and c. AD 720-940 (Ua-4II86 Cal. 2 sigma) (see Figure 5). Excavations at some selected cairn kerbstones indicated ritual offerings. At the base of a red granite kerbstone with natural pits on the outer flat surface placed on the south side of the cairn, we found a ro centimetre ash layer from fire and offering of two types of pottery and four beads (two of glass paste, one of amber and one of quartzite). The finds indicate a date to the Vendel Period and the two radiocarbon dates to $c$. AD 420-565 (Ua-4488I Cal. 2 sigma) and $c$. AD 550-650 (Ua-44880 Cal. 2 sigma) confirm the typological date (see Figure 5). We also found traces of a fire and a deposition of an iron knife and a whetstone at the base of another kerbstone. This event was associated with charcoal which is dated to $c$. AD $430-610$ (Ua-44883 Cal. 2 sigma) (see figure 5). At a concave stone just south-west of the cairn we discovered a stone-lined well in which quartz flakes and a hammer stone were found. A charcoal sample from the well indicates that the activities can be dated to $c$. AD 225-400 (Ua-44882 Cal. 2 sigma) (see Figure 5).

Since charcoal from the south stone context gave Iron Age dates, we suggest that these uprights might not be contemporary with the initial construction of the cairn which belongs to the Early to Middle Bronze Age time frame but was standing there before the Iron Age activities. Our investigations concluded that this large cairn site attracted attention and ritual activities during a long time span. Our research also focused on understanding the physical landscape surrounding Digerrjor cairn. The monument is from the Bronze Age, and since the shoreline displacement has had a major effect on changing the landscape since then, our investigation suggests a near-shore location on a small peninsula when the cairn was initially constructed. There are several ship settings from the Late Bronze Age in the immediate area. One ship setting with an attached rounded stone setting was also excavated (Martinsson-Wallin \& Wehlin 20гі:8-22). Burnt bones and unburnt human skeletal bones from this site were dated to the Late Bronze Age and the Early and Late Iron Age, respectively. 


\section{HÄGRÖR CAIRN}

This c. 40 metre large and 5 metre high cairn, with a deep crater in the middle, is situated on the south-west coast of Gotland. A south stone structure next to the cairn and a stone cist of granite stones found 50 metres to the east of the large cairn were excavated by us in 20 I I (Martinsson-Wallin 20I4). In the surrounding area, we found several stones with cup marks, for example on a flat surface just 25 metres to the south of the cairn. Before the stone structure was cleared and excavated it appeared similar to the four erected stones at Digerrojr, but after clearing, we found a displaced stone pavement with five stones in a circle and one stone in the middle (Figure 7). The stones were partially disrupted and had fallen. On the pavement a few flakes of flint and quartz were found. A charcoal sample recovered on the pavement gave a result of $c$. AD 555-650 (Ua-44876 Cal. 2 sigma) (see Figure 5). This date probably shows a reuse of the place (Martinsson-Wallin 20I4). A charcoal sample was recovered just below the pavement stones close to the base of one of the fallen stones. The sample shows a date to $c$. I660-I500 BC (Ua-44877 Cal. 2 sigma) (see Figure 5), which is probably contemporary with the initial use of the site. At the base of the large flat stone with cup marks to the south of the south stone pavement, a few flakes of flint and a whetstone were found. They seem to represent offerings of some kind.

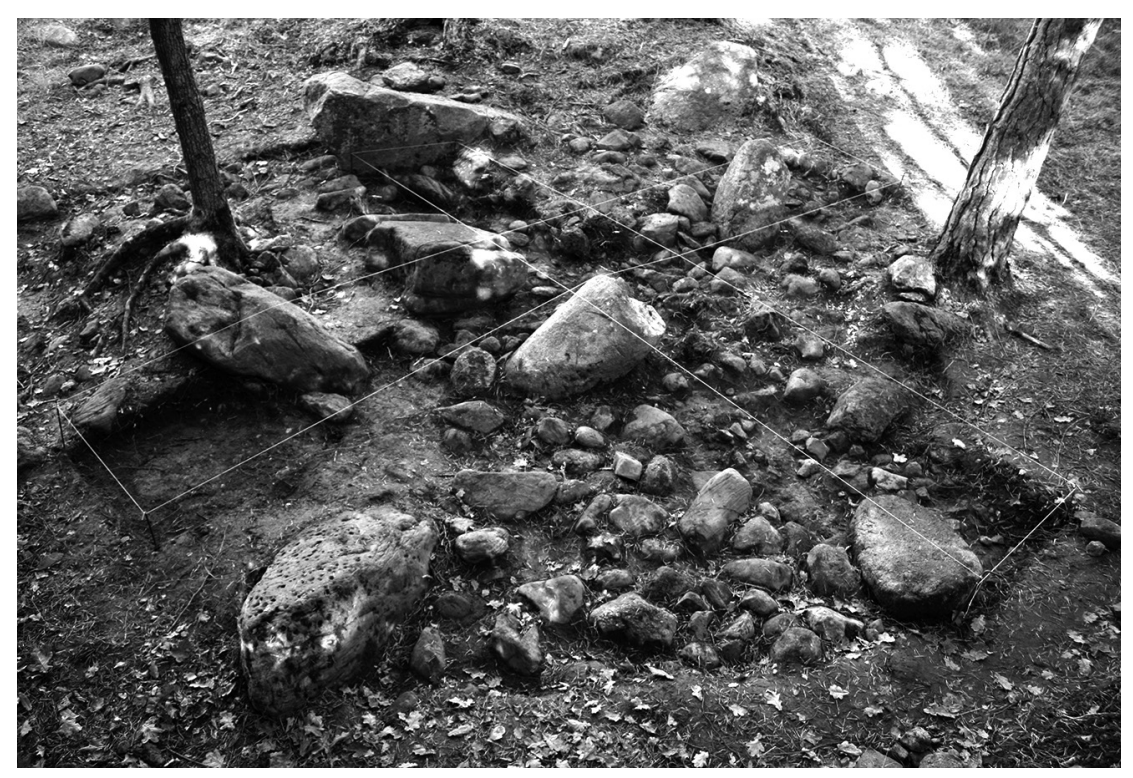

Figure 7. The south structure south-west of Hägrör during excavation 20I2. Photo: Joakim Wehlin. 
A stone cist of erected granite stones to the east of the cairn was partially excavated (Martinsson-Wallin 20I4:8-I5). There were no finds, and we suspect it was looted already in the distant past. In the stone pavement around the cist, there were many flakes of local flint and traces of burning and fire-cracked stones. A rim shard of a pot indicated that the stone cist could be from the Late Neolithic or Early Bronze Age. If this stone cist is from the Late Neolithic, it shows the use of a different material from the limestone slabs on edge that usually make up the Late Neolithic stone cists on the island. However, a dated charcoal sample from this context showed a date to $c .20 \mathrm{BC}-\mathrm{AD}$ I30 (Ua-44875 Cal. 2 sigma) (see Figure 5), which makes the dating of the feature inconclusive. This show that Hägrör is a complex site used for ritual activities from the Late Neolithic until the Late Iron Age.

\section{KOPARVE CAIRN AND OTHER EXCAVATED OR PARTIALLY EXCAVATES CAIRNS}

There are a few cairns on Gotland that have their interior exposed due to excavation or partial destruction of various activities, but Koparve cairn situated in the north of Gotland is the only cairn of monumental dimensions that has been excavated using archaeological methods (Figure 2). Rabbit hunters had partly disrupted the site in the I940s and since then it has been excavated by archaeologists on several occasions. The site was originally a round cairn about 23 metres in diameter and 2.7 metres high made up of granite stones (Stenberger 1942). The rabbit hunters had exposed an interior drywall made up of stacked limestone (Stenberger I942:IOI). Located just south of the cairn four larger limestone slabs are set on edge, shaping a cist-like feature. During the initial investigations by Stenberger in 194I and Arwidsson in I 948 only parts of the cairn were excavated. Stenberger's initial investigation exposed structures made up of an outer and inner drywall of stacked limestone slabs. The drywall was found 2.5 metres from the outer perimeter and is 0.5 metres high. The interior drywall is up to 2.6 metres high. A stone cist was found inside the perimeter of the interior drywall, with two human skeletal remains (Stenberger 1942; Hongslo-Vala 20I0). These remains were typologically dated by Stenberger (1942) to the Bronze Age based on finds defined as belonging to Bronze Age period III, I300-I I00 BC. Arwidsson (I949) made further investigations in 1948 and found another stone cist with a Bronze Age burial. One conventional radiocarbon date was obtained in the I960s, c. I410-910 BC (St-2862 Cal. 2 sigma) (see Figure 5), and sub- 
sequently we obtained several AMS dates from the skeletal remains of three individuals in two stone cists. Two of the skeletal remains were found together in one of the cists, and one was in the other cist. The dates of the two former are $c$. I390-II30 BC (Ua-4II79 Cal. 2 sigma) and $c$. II 20-920 BC (Ua-4II78 Cal. 2 sigma). The other has a previous date to $c$. II90-930 BC (Ua-4I659 Cal. 2 sigma) (see Figure 5). During excavations by Hallström in 1966, human skeletal remains from three adults and one child were recovered between the outer and inner drywall and among the stones (Foglemark 20II). These remains are dated on typological grounds by associated finds to the Late Iron Age (Vendel Period). Additional dated bone samples found among the stones also show reuse during the Late Iron Age and historical intrusions (see Figure 5).

According to Wehlin and Schönbäck (20I2:99-IOO), there are I9 additional investigated Bronze Age cairns on Gotland with a diameter ranging from 8-27 metres. The largest one, a much-destroyed cairn (Vies-Mickelgårds) was examined by Stenberger in Väskinde parish in I940 (Stenberger I94I; Franzén 20I2:28-32). It showed an internal structure much like the one at Koparve, but it was too badly destroyed to give any information on the presence of south stone structures. A partially destroyed cairn of $15-20$ metres in diameter situated in Hau, Fleringe parish, was investigated by Lindquist in 1974-77. There was a similar inner structure here to the one in Koparve, as well as an upright south stone (Lindquist 1976; Franzén 20I2:I I-I6). Two stone settings/ low cairns at Nygårdsrum, Vallstena parish (Hallström 197I) and the nearby Simunde stone setting/low cairn in Hörsne-Bara parish (Wehlin \& Schönbäck 20I2) have been investigated and removed. At least the larger of the ones at Nygårdsrum had several upright stones in a rhombic formation on the south side of the cairn. All three graves showed initial inhumation burials in stone cists dated to Late Neolithic/Early Bronze Age and Early Bronze Age (Hallström 197I). Simunde had been added on and also used in the Late Bronze Age and the Iron Age (Wehlin \& Schönbäck 20I3). Stora Källstäde (Nylén 1959) and Stora Vikers are two other stone settings/low cairn with Late Neolithic/Early Bronze Age inhumation burials and subsequent utilization for cremation deposition and Iron Age burials that have been investigated and removed in Lärbro parish (Rydh I967, I968). They show a structure with concentric circles and a central primary stone cist and secondary burials. The traditional uprights on the south side of the structures were here in the form of markings of stone cists. The remains have been removed at Nygårdsrum and Lärbro but after excavation were restored at $\mathrm{Hau}$ cairn (Lindquist 1979). 


\section{STONE SHIP SETTING CONTEXTS AND SOUTH STONES}

Stone ship settings on Gotland are burial and ritual monuments dated mainly to the Late Bronze Age. These structures are especially common on Gotland. Wehlin (2013:55-60) suggests that there are four different types of ship settings on Gotland. Finds, radiocarbon and typological dates of the ship setting contexts show that type I and 4 seem to be a few hundred years earlier (periods III-IV) than types 2-3 (periods IVV) (Figure 8). Around 300 such monuments are found in the contemporary Gotland landscape and around 80 investigated. It is likely that subsequent activities destroyed several of these types of structures. An example is the Uppgarde ship setting of monumental dimensions. It only remained as negative depressions of where the stones once stood (Englund 1979). Most of the investigated ship settings contain a cremated burial placed in a ceramic vessel, usually a house urn, or a wooden box sealed with resin, sometimes placed in a small stone cist inside the perimeters of the ship setting (Wehlin 20I3:6I). A few excavated ship settings have displayed burnt areas, some with bones inside the perimeter of the erected stones. Some excavated ship settings are without any traces buried bones.

The construction of ship settings ceased after $700 \mathrm{BC}$, but after that time could still be used as sites to bury the dead until c. $200 \mathrm{BC}$ (Wehlin 20I3:68). During this later period, the ship settings mainly contain in-
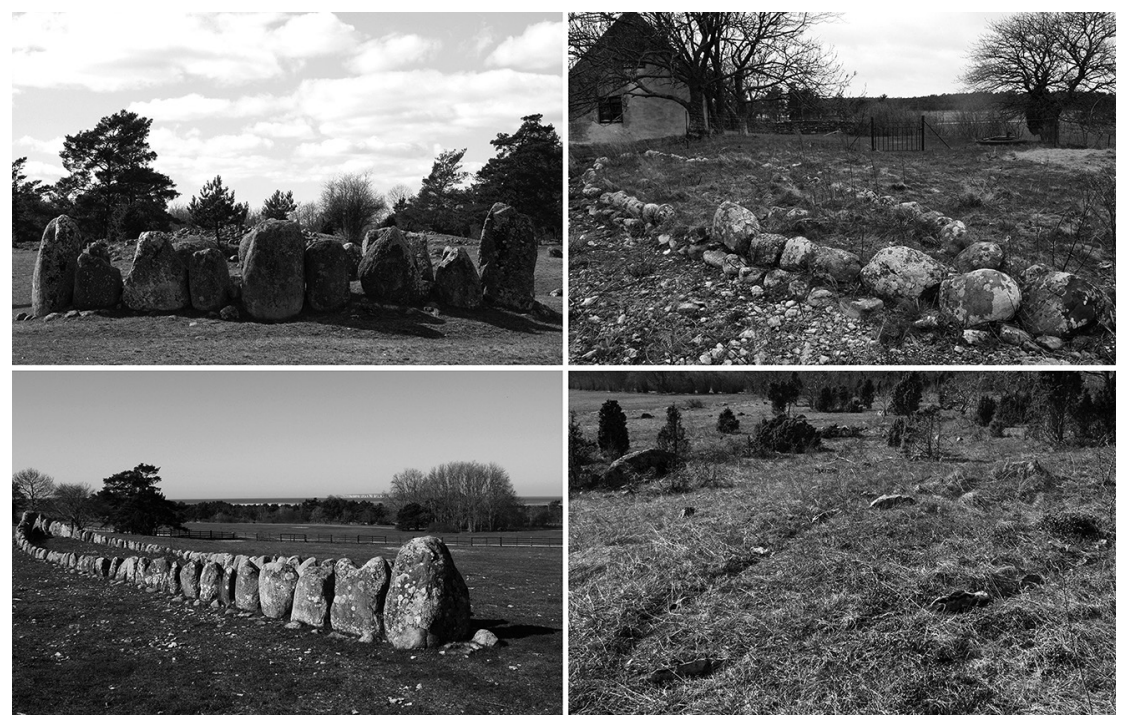

Figure 8. The four types of ship settings on Gotland. Photos: Joakim Wehlin. 
humations. Changes in the burial custom are indicated during Early Pre-Roman Iron Age, 500-200 BC, when another type of smaller boatshaped stone cists appears. They are entirely or partially buried underground, smaller in size, and they only contained inhumation burials (Wehlin 20I2, 2013:74).

Some of the recorded ship settings are discussed as south stone structures (for examples see the Digerrojr and Hägrör investigations above). It is not conclusive, but there are indications that the south stone idea is contemporary with the beginning of the Late Bronze Age. We suggest that they are markings outside the perimeters of the 'room of the dead'. This 'room' has inside concentric circles of stone and dry-walls of stacked limestone slabs. Some have been covered by granite stones to form high cairns and some as low cairns/stone settings.

It is likely that ritual activities were carried out at south stone structures. A radiocarbon-dated sample from under the pavement with south stones at Hägrör cairn could indicate that this structure was built later than the initial burial site. Considering the south stone complex at Digerrojr cairn, the dates were ambiguous and showed Iron Age use of the site. However, the stone heap that surrounded the standing stones consisted of fire-cracked stones, probably deriving from a ritual tied to Late Iron Age ritual practices. It is clear that the standing stones had been erected before the fires were lit here since they were fire-cracked at their bases. It seemed as if the area was cleaned after the event(s) since few charcoal remains were found, mostly only ash and red, burnt soil. Wehlin and Schönbäck have argued elsewhere (20I2:94-II3) that the south stone structures were additions to the cairn milieu during the Late Bronze Age or later. In line with the argument from Lindquist (1976:I24) they suggest that the erected stones just outside the perimeters of the cairns or larger stone settings marked the primary grave when the grave was 'sealed' under a dry walls heap during the Late Bronze Age. Thus, based on our own and others' investigations we suggest that the erection of south stones and ritual activities carried out on the south side of cairns fits the Late Bronze Age time frame. This was a time when the earlier burial grounds were covered with stones to form cairns, and a new burial and ritual type of site emerged, the stone ship setting. The burial and ritual practice in connection with this probably changed quite rapidly in periods III-IV ( $\mathrm{I} 300-900 \mathrm{BC})$.

To understand whether there have been any connection between the practice of placing standing stones close to the cairns, usually in south to south-west position, and the practice of erecting ship settings, Wehlin (20I3:72-74) has investigated their spatial relationship. The majority of the stone ships are oriented to 'sail' towards the south, and Wehlin shows that they often are found on the south side of the cairn or stone setting. 


\section{COVERING AND MOVING - FROM THE CONCENTRIC CIRCLES TO THE 'SHIP SHAPE'}

Archaeological excavation, finds and radiocarbon dates have shown that investigated cairn and stone setting sites on Gotland, generally interpreted to belong to the Bronze Age, usually have an extended use and reuse, spanning from the Late Neolithic to the Late Iron Age (Stenberger I94I; Rydh I967, I968; Lindquist I979; Martinsson-Wallin \& Wehlin 20IO, 20II; Martinsson-Wallin 20II; Wehlin \& Schönbäck 2OI2; Martinsson-Wallin 2OI4). The re-dating of the Koparve skeletal remains by Martinsson-Wallin has shown that the three Bronze Age burials inside the inner wall structure are not contemporary with each other and thus the monument displays a succession of utilization during the Bronze Age. Also, this site was used for inhumation burials during the Late Iron Age. These new results together with data on the reuse of Late Neolithic stone cist burials surrounded with concentric stone circles (Rydh I967, I968; Lindquist 1976), as well as ritual offerings made at some of the kerbstones of large cairns (Martinsson-Wallin \& Wehlin 2OIO, 2OII), show that some of these places have a complex biography and were utilized from the Late Neolithic through the Bronze Age and well into the Late Iron Age.

When using the practice perspective, we can see that the norm in the Early Bronze Age burial practice is a stone cist with inhumation(s) placed in the middle of one or several concentric stone circles. One or two of the circles are usually higher and made up of masonry walls of stacked limestone. Wehlin \& Schönbäck (2012:IO4-IO6) discuss the concentric circles as representing the outer kerb. When the burial place was reutilized additional kerb circles were built, but they add that some graves originally had several stone circles surrounding the stone cist. The norm for the selection of special stone material in the cairn milieus is apparent. Limestone slabs were used to make the cists and the low concentric walls. Rounded granite stones make up concentric circles and the cairn fills. In some places, as at Nygårdsrum and Stora Vikers cairns, there were postholes associated with the stone cists, and osteological analysis of the human skeletal remains indicates that many young individuals had been buried or perhaps offered at the sites (Hallström I97I; Rydh I967). We also see a tendency that if the stone cist is from the Late Neolithic, there are usually several people buried in the cist. If the cist was made in the Bronze Age usually just one or two individuals were buried in each cist (Rydh I967; Burenhult I986; Martinsson-Wallin 2010). Cup marks and flaking of quartz and flint and the relationship of fire and water relate to the cairn milieus and south stone structures. Ship set- 
tings have carefully selected large granite boulders set on edge with flat sides. The selected stone material, concentric circles, flaking and cup marks, among other materialized phenomena, have also been discussed concerning Bronze Age burial contexts in mainland Sweden by Goldhahn (2006, 2016) and Thedéen (2004). Kaliff (2007) and Kaliff and Østigård (2013) have, for example, discussed fire and water as agents in Bronze Age contexts.

The archaeological find material in the stone cists is ambiguous to interpret since it is likely that some of the investigated graves were looted already in ancient times. However, the finds indicated that in the Late Neolithic/Early Bronze Age weapons such as daggers and swords were common and in the Late Bronze Age we more find razors, tweezers, jewellery and double-buttons. It is also usual that there is more than one inhumation in the stone cist, which signals that it may be a grave probably for a family group. The redating of the Early Bronze Age Koparve burials gives us reason to believe that the burial ground was 'open' during the early stage of the Bronze Age and that it subsequently was closed during the Late Bronze Age. An alternative interpretation is that burial cairns were 'opened' and 'closed' several times to host additional burials.

The practices seen in connection with stone cist graves are interpreted by us as serving as a ritual and burial ground alike, with adjoining posts, erected stones and pavements for an extended family group. Some of these sites, especially large ones, were subsequently covered and sealed during the Late Bronze Age when the ship settings and another form of treatment of the dead - the cremation - entered the scene. Our investigations indicate that the erection of south stone structures was done when the stone cists and concentric stone circles were sealed, but further research needs to confirm this. In metaphoric/cognitive and factual ways alike, we interpret south stones as markers of the entrance and exit of the 'room of the dead'. The importance of the earlier burial places, now covered with rocks, was still recognized as being tied to the genealogies and the mythological past. See the discussion of the Kivik grave of Bredarör in Scania (Goldhahn 20I3). Sometimes cremations were placed as secondary burials among the stones in some of the cairns.

The new cremation burial practice in the Late Bronze Age is linked to the construction of ship settings on Gotland. Wehlin (2013:70-73) has argued that such structures are symbolic ships that with time 'sailed' out from the original burial place during the shift from the Early to Late Bronze Age, c. I200-II00 BC (based on Artelius' discussion 1996). Thus, the ship symbol is a liminal agent that is a mediator between the living and the dead and the gods. Based on Wehlin's investigations of ship settings on Gotland (2013) we suggest that ship structures could 
still have had a role as liminal agents when they became free-standing monuments in period V. It is transformed from a symbol to a physical reality while still serving as a symbol. We suggest that the physical ship setting works as a liminal mediator, but the ship also took on a new meaning connected to the rise of a maritime institution on Gotland during the Late Bronze Age.

In practice, the concentric circles and inhumations are covered up with rounded granite stones 'harvested' from the fields or the seashore (Nilsson 198I) to form cairns. Perhaps the south stones and stone ships were constructed in succession to one another, the former representing a ritual place for ancestral cult that focuses on genealogies, mythologies and inhumation practices tied to land and the latter representing the new ritual practices associated with a maritime institution (Bradley \& Widholm 2007:25-27), the cremation practice and a new god (Kaliff \& Østigård 2013:95). Late Bronze Age is a time of increasing external interaction and possibly also the arrival of new groups, from the south (La Tène culture) when new ideas about how to treat the dead, i.e. cremation and placing the placed in house urns, show the changes in society (Wehlin 2013:I83-I95).

\section{DECODING BRONZE AGE RITUAL PRACTICE ON GOTLAND - A DISCUSSION}

In this paper we focus on the investigation of the relationships between the Bronze Age cairns and the so-called south stones that are found outside the perimeters of many Bronze Age cairns. We have also included a discussion of the relationship of the 'inside' and 'outside' milieu of the cairns. Our investigations have highlighted both Bronze Age and long-term ritual practices. In line with Berggren and Nilsson Stutz (20I0:I86-I9I) who discuss the long-term ritual actions at the fen at Hindbygården, we have focused on the activities, what people were doing, at Bronze Age cairns on Gotland. It has not been easy to tease apart and make a chronology of various features at the cairn sites. The 'sealed' cairns and ship settings are found all around the Island, and chronologically we link the rise of the two phenomena to the transition between Early and Late Bronze Age.

There has been considerable shoreline displacement on Gotland since the Bronze Age. Our analysis of LiDAR data and detailed m.a.s.l. estimations show that large cairns that now are situated one or two kilometres inland dotted the coastline during the Bronze Age. Many of the ship settings were located close to the Bronze Age coast as well (Figure 9). We interpret the ancient Bronze Age seashore as a kind liminal zone. 
The cairns themselves and adjacent structures are associated with ritual practices to do with the burial act and commemoration of the dead, which has a strong connection to both the sea and the land. We interpret the Bronze Age conception of the sea as separating and needing a medium, a boat, to connect to other places that for example provided prestige goods and also an important source of subsistence. We suggest that people living on an island have a special relationship to the sea. The

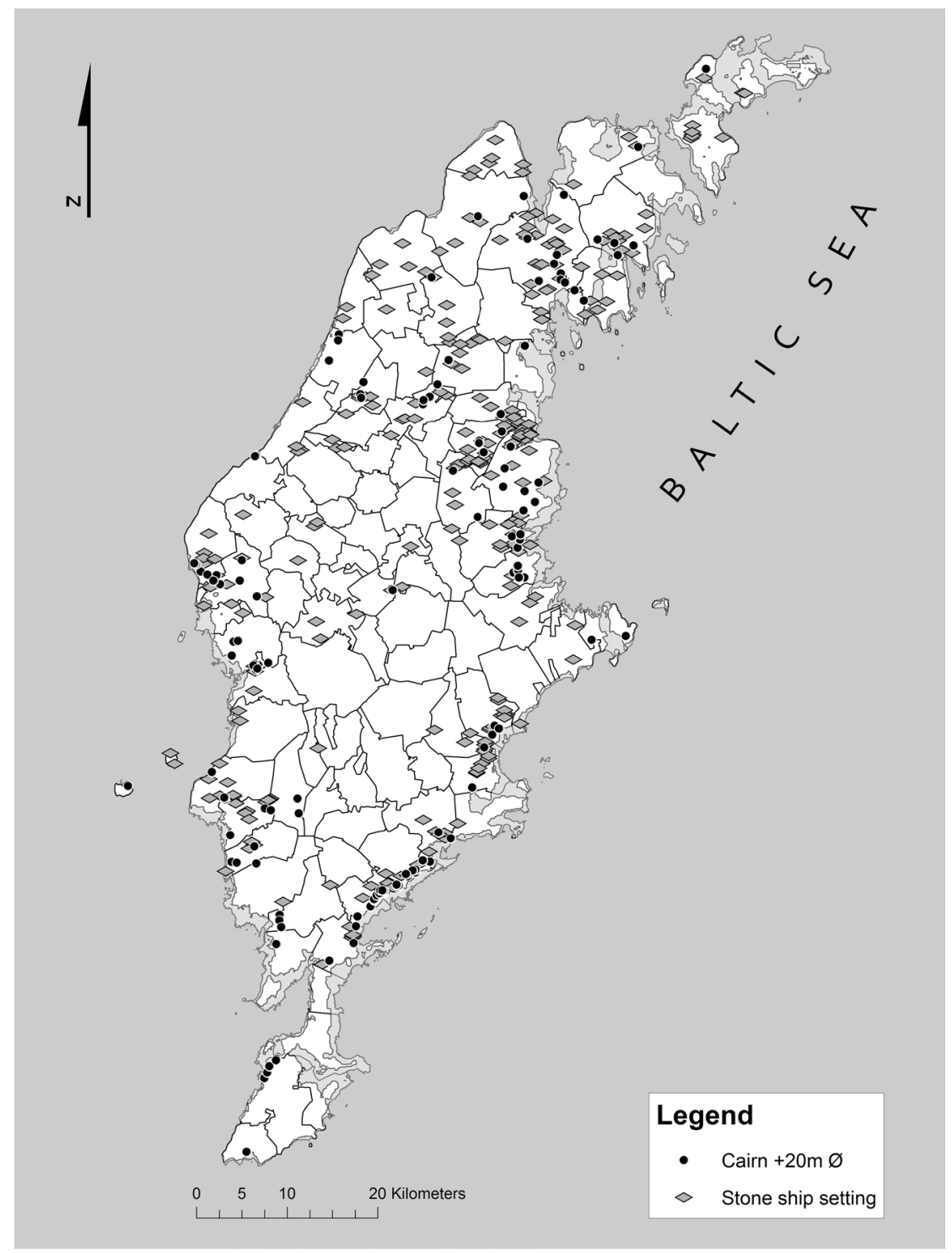

Figure 9. Larger cairns and ship settings on Gotland. Illustration: Anton Uvelius. 
liminal near-shore zone is not suitable for farming, but, for example, for herding and harbours/landing places for fishing and for trading goods. It is likely that these harbours/landing places were distributed around the Island, near nodes with large-scale cairns. The near-shore location of the 'rooms of the dead' on Gotland differs from the placing of large Bronze Age mounds in Denmark, which show a strong connection to fertile farmland (Kristiansen I998). The materials used for the building of burial monuments and their implications regarding social structure also differ between Denmark and Gotland. Bronze Age monuments in Denmark are made up of soil and peat, and according to Holst et al. (Holst et al. 2004; Holst \& Rasmussen 2013, 2015) and Goldhahn (2006), this indicates a conscious 'offering' of fertile soil. This is contrasted to the material for building the Bronze Age burial places on Gotland, which consists of 'harvested' stones from the seashore or the land. These actions make farmland easier to manage, and stones from the seashore make certain places more easily accessible for mooring (Nilsson I98I, I986). The building practices are linked to the conditions of the physical landscape, but also to the ideas and structures inherent in society. The near-shore zone on Gotland is a rich and fertile place that was important to control, and the cairns became nodes for ritual actions to do with life and death. The south stones, sometimes accompanied by pavements/platforms, were probably constructed in the Late Bronze Age and became ritualized places used for a long time span. Through our case studies, we have been able to detect materialized ritual activity that included the flaking of stones, mainly of flint and quartz (Masojć 20I6). Other activities that have left traces in the cairn milieus are the use of fire and fire-cracked stones, and the making of cup marks and selected stones materials. We suggest that the actual placing of south stone uprights and platforms and stone settings in a southerly location show a norm, a prevailing idea of a specific significance of the south or south-west direction of these structures. The south stones and the cairns that contained human burials have a relationship invested with meaning. Wehlin (20I3:84, I44-I 46) has shown with his study of ship settings that most of them 'sail' south i.e. have their bow towards the south and stern towards the north. One area on Gotland that contrasts this norm is the Lina Mire area on the north-east of Gotland. The agglomeration of ship settings found here shows that most of them are aligned parallel to the Lina Mire/Gothem river waterway in eastwest direction (Wehlin 20I0). We suggest that the structural principles of the placing and orientation of the ship settings are primarily their relationship to the seashore/waterways.

On Gotland, upright stones and platforms/stone settings on the south side of the cairn seem to be the practice and norm, and this materialized 
phenomenon has not been recorded to a great extent in other places with cairns/mounds from the Bronze Age in Scandinavia. However, the importance of ritual practice and south location is indicated, for example, in the 'south houses' interpreted as ritual sites attached to large Bronze Age mounds in Denmark (Nielsen \& Bech 2004). The importance of a southerly location is suggested at the large Bredarör cairn on the southeast coast of Sweden, by the stones (the so-called prince grave) located in the south and a house structure that could be a cult house south of the cairn (Goldhahn 2006, 20I3). Furthermore, Thedéen (2004:92-IO3) stresses that gaps/openings are found in a southerly location in the concentric kerbs of Bronze Age cairns in mainland eastern Sweden.

During the Late Bronze Age ship settings appear on Gotland, and they often contain cremated individuals buried in urns. Some of these urns have the shape of houses. House urns are also found, for example, in Poland and northern Germany (Sabatini 2007). The building of ship settings seems to be the norm on Gotland during the Late Bronze Age. Besides Gotland, this phenomenon also occurs in the south-west Baltic area (Werner 2003; Widholm 2007), on the islands of Bornholm, Åland, Öland and a few in the Baltic States that belong to the Bronze Age time frame (Wehlin 20I3:I2-I5).

We suggest that some of the burial places in the form of stone cists with concentric circles that started out as collective graves in the Late Neolithic became more individualized and covered in the shift from Early to Late Bronze Age. South stone structures became more important as places where ritual acts were performed to commemorate the dead inside the cairns. We suggest that south stone structures and adjacent pavements were part of an ancestral cult. Some stone cist burial sites constructed in the Late Neolithic were abandoned in the Bronze Age. These were not covered, and new sites emerged in Early Bronze Age that were more individualized than before. We suggest that during the course of the Bronze Age there was increasing focus on the coastline as a ritualized landscape with the structuring principles of large cairns as nodes/'islands', situated in the liminal zone between water and land. The sea/water and stones are the primary structuring principles in this ritualized landscape, a southern location and fire seem to be secondary.

\section{MILIEUS}

The built milieu outside the cairns includes the erected stones and platforms in a southern location for rituals close to the perimeters of the cairns. We suggest that the changes of this outside built milieu are closely 
connected to the changes over time of the inside milieu, the 'room of the dead'. The Late Neolithic stone cists contain collective burials of a descent group. These open stone cists were also for the most part located close to the seashore, but these were not monumentalized (Wallin 20I0). The collective stone cist building practice seems to cease in Bronze Age period I. Some of the cist structures continued to be used. In Bronze Age periods II and III these corporate practices changed to individual burials. We suggest that it was still possible to access the 'room of the dead' since the monument, as in the Koparve case, was in continuous use for burials. It is likely that there were erected stones, platforms or wooden poles at the outside perimeter of the concentric circles that surrounded the stone cists. The demarcation of the south direction might not have been a common idea during the Late Neolithic and Early Bronze Age. The inhumation practice and burials in stone cists ceased at the end of period IV and the beginning of period $\mathrm{V}$ when the cremation practices became the norm. This was probably the time when the inner room of the dead' finally was closed off. In some cases, in areas with principal chiefs, the cairns became of monumental dimensions. South stone structures were tied to the outer perimeter of the cairns to commemorate the dead and worked as mediators between the living, the dead and the gods related to genealogies and mythologies. We suggest that the south stone structures became symbols of the ship structures that 'sailed' out from the 'inner room of the dead'. Secondary burial in the form of cremations are found in some of the cairns, but a new monument, the ship setting, was erected on Gotland. Most of them contained cremation burials, often with cremated bones placed in house urns or stone cists inside the perimeter of the ship setting. The cremation practice was a new way of dealing with the body of the deceased. The south direction seems to become of increasing importance in the Late Bronze Age, although the sea and water were still the primary structuring principle. Most of the newly erected ship settings are 'sailing' towards the south and when close to large cairns they are placed to the south of them. Wehlin (2OI3:I44-I46) also suggest that type 2-3 ship settings (probably copies of real ships) have demarcations of uprights south of the prow, interpreted as South structures.

From period VI to the Pre-Roman Iron Age, inhumation burials reoccur in connection with south stones, ship settings and smaller boatshaped stone cists. They seem to be connected to particular groups in the society (Wehlin 2OI2, 20I4). The burial grounds moved closer to the settlements, and old burial sites were abandoned. The structuring principle for the burial monuments changed from water/sea to the settlement and farmland. This reflects a change in the social structure of the society, 
but some of the monumental cairns were still important and continued to be used as ritual sites at least to the Late Iron Age (Martinsson-Wallin $\&$ Wehlin 20Io; Martinsson-Wallin 20II). Due to the shoreline displacement, the Bronze Age sites are currently located inland. The south direction still seems to be structuring principle tied to burial practices since, according to Nylén (1993), south stones occur as a phenomenon in Iron Age graves but then in the form of smaller limestone slabs.

In this paper we have especially focused on decoding the Bronze Age ritual practices. In these practices we can see that the agents - the humans, the stones, water and fire - influenced each other and created a materialized ideology. This took the form of cairns, ship settings, uprights and platforms situated close to the seashore and tied to events that produced fire-cracked cairns and stone flaking. By investigating the practices, structures and relationships of features at these sites, we have tried to detect the ontologies of Gotland Bronze Age people. Here we see that the stones of rounded granite are tied to the 'outside'. Limestone slabs linked to the 'inside' and the flaking is transformative and maybe also an act of covering. Water connects and separates, perhaps as a life-giving and life-ending force; fire is cleansing and transformative (cf. Kaliff 2007). Archaeological excavations have shown that south stone structures are connected to acts of stone flaking and fire making as a ritual behaviour.

We want to conclude this paper by stressing that our ambition with the investigation of the relationships of the built and physical milieu, of the Bronze Age cairns has been to arrive at a holistic understanding of past ritual behaviour, which goes beyond the interpretation of the Bronze Age cairns only as depositing places for the dead. We have primarily focused on what the Bronze Age people were doing, and we have aimed to detect their practices and norms, and also what deviates from the norms. Our investigations confirm that cairns and the south stone structures show the complex relationship between the living, the dead and the gods tied to genealogies, mythologies and cosmologies in a long-term perspective.

Our aim has also been to try to decode and understand these practices. As suggested above, it is likely that the sea/water had a special meaning in Gotlandic Bronze Age society and that this medium affected the cosmology and worldview in the real world and the view of the afterworld. The maritime relationship where the seashore/coast was a liminal zone and a place for rituals and burial monuments existed for a long time in Gotlandic society. This relationship is stressed already in Neolithic times (Wallin \& Martinsson-Wallin 20I6). Another aspect of the spatial relationships of large cairns is their deliberate placing on or close to borders between different territories. Carlsson (I983) discusses 
the cairns spatial distribution in a matter-of-fact approach as caused by territorial behaviour. It is likely that the spatial structure of communities of Gotland that we know as the parish system from historical times started to be formed already during the Late Bronze Age. The spatial distribution show that large cairns and stone ship settings are on the boundary between land and sea, and probably also between different family group areas. However, we suggest that this should not be seen only as a practical matter but that it also shows relationships between the people and their cognitive and physical landscape.

We suggest that our research results mirror the Bronze Age social landscape on Gotland and the rise of a social system with agglomeration of power to certain individuals/kin groups that controlled preferred port locations, and could claim land to herd livestock such as sheep and cattle. This relates to a rise of a maritime institution tied to the bronze (copper/ tin) trade/bartering. Since the large sites and stone ships are distributed all over the island, this indicates a highly competitive social landscape, but this issue needs further elaboration that is beyond the scope of this paper.

\section{SUMMARY}

In this paper we have discussed Bronze Age cairn environments and socalled south stones and widened the concept to south stone structures that are one or more uprights attached to the cairns to the south and south-west of the cairn. Our starting point has been our investigations of three large-scale cairn milieu, Uggarderojr, Digerrojr, Hägrör. We have also included data and redating from previous excavations of the cairn at Koparve, as well as previous investigations of ship settings. This research has indicated that the burial custom of stone cists surrounded with concentric circles was initiated in the Late Neolithic/Early Bronze Age and such sites were probably covered with stones in the Late Bronze Age and transformed into cairns. The south stones were erected and served as markings for the graves, maybe as a symbol for the genealogies. These upright stones also served as places for ritual behaviour including flaking and making fires. We have argued that the concept of 'south stone' also is associated with ship settings. The ship was a symbol that initially was connected to the 'inner room' of the Late Neolithic-Early Bronze Age stone cists surrounded by inner and outer walls and concentric circles, and then in the Late Bronze Age they 'sailed' out towards the south. This was when the idea of the of the treatment of the body changed from inhumation to cremation that these stones were erected and became ritual nodes probably tied to water and fire as agents in this 
ritual. The stones in the south can very well be interpreted an intermediate step and form a link between cairns and the ship settings in the Bronze Age ritual practices.

\section{ACKNOWLEDGEMENTS}

We want to thank all students involved in the archaeological excavations. Our gratitude is also directed to the reviewers for some relevant pointers to make this paper better and to editors of this journal. The Berit Wallenberg Foundation, DBW Foundation and Gotland University College have graciously financed our research.

\section{REFERENCES}

Aner, E. \& Kersten, K. 1973-. Die Funde derälteren Bronzezeit des nordischen Kreises in Dänemark, Schleswig-Holstein und Niedersachsen. København: Nationalmuseum.

Artelius, T. 1996. Långfärd och återkomst: Skeppet i bronsålderns gravar. Lic.-avh. Göteborg: Göteborgs universitet.

Arwidsson, G. I949. Undersökning av hällkista i bronsåldersröse. Gotland, Lärbro sn. Koparve I22. Rapport. Gotlands museum Konc. nr. $30 / 49$.

Baudou, E. I960. Die regionale und chronologische Einteilung der jüngeren Bronzezeit im Nordischen Kreis. Diss. Stockholm: Stockholms universitet.

Bell, C. M. (1992). Ritual Theory, Ritual Practice. New York: Oxford University Press.

Berggren, Å. \& Nilsson Stutz, L. 20Io. Ett utmanat koncept? Ritualbegreppets möte med arkeologin. In: Hornborg, A.-C. (Ed.). Den rituella människan: Flervetenskapliga perspektiv. Pp. 3 I-58. Linköping: Linköping University Electronic Press.

Bourdieu, P. 1977. Outline of a theory of practice. Cambridge: Cambridge University Press.

Bradley, R. \& Widholm, D. 2007. Bronze Age Cosmology in the South-West Baltic: A framework for Research. In: Widholm, D. (Ed.). Stone Ships:. The Sea and the Heavenly Journey. Pp. I3-48. Institutionen för humaniora och samhällskunskap. Kalmar: Högskolan i Kalmar.

Bronk Ramsey, C. 2009. Bayesian Analysis of Radiocarbon Dates. Radiocarbon 5I(I). Pp. 337-360.

Burenhult, G. 1986. Speglingar av det förflutna. Höganäs: Bra bok.

Carlsson, D. 1983. Bronsåldern: Tiden för kulturlandskapets territoriella framväxt och etablering på Gotland. Ett försökt till förklaringsmodell med utgångspunkt från gotländska förhållanden. In: B. Stjernquist (Ed.). Struktur och förändring i bronsålderns sambälle: Rapport från det tredje nordiska symposiet för bronsåldersforskning i Lund 23-25 april I982. Vol. I7. Pp. 23-36. Historiska museet report series. Lund: Lunds universitet historiska museet.

Englund, S. 1979. Uppgarde i Vallstena. In: Falck, W. (Ed.). Arkeologi på Gotland. Gotlandica I4. P. 53. Visby: Press. 
Foglemark, T. 20I I. Kauparve: En osteologisk studie av tre sekundärbegravningar från Vendeltid på Gotland. Kandidatuppsats i osteologi. Visby: Högskolan på Gotland.

Franzén, E. 20I 2. Komplexitet $i$ sten: En jämförande analys av inre samt yttre gravoch byggnadsstruktur hos fem gotländska bronsåldersrösen. Kandidatuppsats i arkeologi. Visby: Högskolan på Gotland.

Gansum, T. 2002. Fra jord til handling. In: Jennbert, K. et al. (Eds). Plats och praxis: Studier av nordisk förkristen ritual. Pp. 249-286. Lund: Nordic Academic Press.

Gansum, T. 2004. Hauger som konstruksjoner: Arkeologiske forventninger gjennom 200 år. Diss. Göteborg: Göteborgs Universitet.

Goldhahn, J. 2006. Från landskapens monument till monumentens landskap: Om döda och efterlevande med exempel från äldre bronsålder, I700-I I00 cal BC. In: Østigård, T. (Ed.). Lik og ulik: Tilnæerminger til variasjon i gravskikk. Pp. I7 I-202. Bergen: Arkeologisk institutt, Universitetet i Bergen.

Goldhahn, J. 2013. Bredarör på Kivik: En arkeologisk odyssé. Simrishamn: Artes liberals.

Goldhahn, J. 20I6. Sagaholm: North European Bronze Age rock art and burial ritual. Oxford: Oxbow.

Hallström, A. I97r. Boplats och gravar på Nygårdsrum i Vallstena. Gotländskt Arkiv. P. II4. Visby.

Hansson, H. 1927. Gotlands bronsålder. Stockholm: Kungl. Vitterhets-, historie- och antikvitetsakademien.

Holst, M. K., Rasmussen, M. \& Breuning-Madsen H. 2004. Skelhøj: Et bygningsværk fra den ældre bronzealder. Nationalmuseets Arbejdsmark. Pp. I I-25.

Holst, M. K. \& Rasmussen, M. (Ed.) 2013. Skelhøj and the Bronze Age barrows of Southern Scandinavia I: The Bronze Age tradition and the excavation of Skelhøj. Højbjerg: Jutland Archaeological Society.

Holst, M. K. \& Rasmussen, M. (Ed.) 2015. Skelhøj and the Bronze Age barrows of Southern Scandinavia 2: Barrow building and barrow assemblies. Højbjerg: Jutland Archaeological Society.

Hongslo-Vala, C. 20Iо. Bronsåldersröset $i$ Kauparve på Gotland: En humanosteologisk analys av fem individer. Osteologisk rapport. Visby: Högskolan Gotland.

Hyenstrand, Å. I968. Gravformer och symboltecken under yngre bronsålder. Fornvännen 63. Pp. I85-189.

Kaliff, A. 2007. Fire, water, heaven and earth: Ritual practice and cosmology in ancient Scandinavia. An Indo-European perspective. Stockholm: Riksantikvarieämbetet.

Kaliff, A. \& Østigård, T. 2013. Kremation och kosmologi: En komparativ arkeologisk introduktion. Uppsala: Uppsala universitet.

König, L. 2007. A landscape of cairns. In: Widholm, D. (Ed.). Stone Ships: The Sea and the Heavenly Journey. Pp. 50-96. Kalmar: Institutionen för humaniora och samhällskunskap, Högskolan i Kalmar.

Kristiansen, K. 1998. Europe Before History. Cambridge: Cambridge University Press.

Kristiansen, K. \& Larsson, T. B. 2005. The rise of Bronze Age Society: Travels, Transmissions and Transformations. Cambridge: Cambridge University Press.

Lindquist, S.-O. 1974. The Development of the Agrarian Landscape on Gotland during the Early Iron Age. Norwegian Archaeological Review 7. Pp. 6-32.

Lindquist, M. 1976. Bronsåldersröset vid Hau i Fleringe: Preliminär analys för slutgiltig undersökning. Gotländskt Arkiv. Pp. I2 I-I 24. Visby: Gotlands museum. 
Lindquist, M. 1979. Storrösen. In: Falck, W. (Ed.). Arkeologi på Gotland. Pp. 33-4I. Gotlandica I4. Visby: Gotland University Press.

Malmström, H., Gilbert M. T. P., Thomas M. G., Brandström, M., Storå, J., Molnar, P., Andersen, P. K., Bendixen, C., Holmlund, G., Götherström, A. \& Willerslev, E. 2009. Ancient DNA Reveals Lack of Continuity between Neolithic HunterGatherers and Contemporary Scandinavians. Current Biology I9. Pp. I758-I762. doi: I0.I0I6/j.cub.2009.09.017.

Martinsson-Wallin, H. 20I0. Bronze Age Landscapes on Gotland: Moving from the Neolithic to the Bronze Age Perspective. In: Martinsson-Wallin, H. (Ed.). Baltic Prehistoric Interactions and Transformations: The Neolithic to the Bronze Age. Pp. 63-77. Visby: Gotland University Press.

Martinsson-Wallin, H. 20I I. Rapport frän arkeologisk undersökning vid Digerrojrröset 20II. Gotland Garda sn. Folkdarve I:2 I, Goks I:8, RÄ̈ Garda I: I,2,3. Arkeologisk Rapport. Visby: Högskolan på Gotland.

Martinsson-Wallin, H. 20I4. Rapport från arkeologisk undersökning av rösemiliön runt Hägrör, RÄ̈ Sanda I3:I. Gotland. Visby: Högskolan på Gotland.

Martinsson-Wallin, H. n.d. Åter till Koparvegraven: Om återknytande till en gravplats i dåtid och nutid. (unpublished manuscript).

Martinsson-Wallin, H. \& Wallin, P. 20I6. Collective Spaces and Material Expressions: Ritual Practice and Island Identities in mid-Neolithic Gotland in the Baltic Sea. In: Nash, G. \& Townsend, A. (Eds). Decoding Neolithic Atlantic and Mediterranean Island Ritual. Pp. I-I5. Philadelphia: Oxbow Books.

Martinsson-Wallin, H. \& Wehlin, J. 20I0. Rapport från arkeologisk undersökning $i$ Uggarderojrområdet 2009. Gotland, Rone sn, Uggårda 3:I, RAÄ I0:I,3,4,5. Institutionen för kultur, energi och miljö, Avdelningen för arkeologi. Visby: Högskolan på Gotland.

Martinsson-Wallin, H. \& Wehlin, J. 2ог I. Rapport från arkeologisk undersökning $i$ Rojrskogen 20I0. Gotland, Garda och Lau sn. Goks I:8 RÄ̈ Garda I:2-3 och Lau 4I:I. Institutionen för kultur, energi och miljö, Avdelningen för arkeologi. Visby: Högskolan på Gotland.

Masojć, M. 2016. Late Bronze Age Flintworking from Ritual Zones in Southern Scandinavia. Oxford: Archaeopress.

Masojć, M. \& Bech, J.-H. 20I . Cult Houses and Flint Knapping in the Scandinavian Late Bronze Age. Acta Archaeologica 82. Pp. 203-226.

Nielsen, B. H. \& Bech, J.-H. 2004. Bronzealderens kulthuse i Thy: Anlæg med relation til gravkulten. KUML. Årbog for Jysk Arkcologisk Selskab. Pp. I29-I59.

Nilsson, P.-E. I98I. Om bronsåldersgravars läge på Gotland. Unpublished thesis. Department of Human Geography. Stockholm University.

Nilsson P.-E. 1986. Bronsåldersrösen: En korologisk studie med persondator. In: Nordiskt symposium för bronsåldersforskning: Det 4. Nordiske bronsealdersymposium på Isegran I984. Pp. 67-87. Varia no. I2. Oslo.

Nylén, E. 1958. Gotländska gravformer och deras betydelse för kronologien. TOR. Vol. IV:I958. Pp. 64-86.

Nylén, E. I959. Gotlands murade rösen och bronsålderns fjärrhandel. Gotländskt Arkiv. Pp. 9-34. Visby: Gotlands museum.

Nylén, E. 1993. The Stones in the South. TOR. Pp. II9-I 27.

Oldeberg, A. 1974-1976. Die ältere Metallzeit in Schweden. Stockholm: Kungl. Vitterhets-, historie- och antikvitetsakad. 
Reimer, P. J. et al. 2013. IntCalı3 and Marines3 Radiocarbon Age Calibration Curves 0-50,000 Years cal BP. Radiocarbon 55(4). Pp. І869-1887.

Rydh, S. 1967. St. Vikers, Lärbro sn. Gotland. ATA Dnr. 28I7/67.

Rydh, S. 1968. Ett gotländskt fynd av benpilspetsar från bronsåldern. Fornvännen 63 . Pp. I53-I65.

Sabatini, S. 2007. House urns: Study of a Late Bronze Age Trans-Cultural Phenomenon. Diss. Göteborg: Göteborgs universitet.

Stenberger, M. I94I. Gotländska bronsåldersrösen. Gotländskt Arkiv. Pp. I5-40. Visby: Gotlands museum.

Stenberger, M. 1942. Ett kraterröse på Gotland. Fornvännen 37. Pp. 95-II4.

Svensson, L. 20Iо. Osteological Analysis from Uggarde RAÄ го: I, Iо:3 and ıо:4, Rone parish on Gotland. In: Martinsson-Wallin, H. \& Wehlin, J. (Eds). Rapport från arkeologisk undersökning i Uggarderojrområdet 2009. Gotland, Rone sn, Uggårda 3:I, RA ̈̈ IO:I,3,4,5. Pp. 28-32. Institutionen för kultur, energi och miljö, Avdelningen för arkeologi. Visby: Högskolan på Gotland.

Thedéen, S. 2004. Gränser i livet: Gränser i landskapet. Generationsrelationer och rituella praktiker $i$ södermanländska bronsålderslandskap. Stockholm Studies in Archaeology. Stockholm: Stockholms universitet.

Wallin, P. 20IO. Neolithic Monuments on Gotland: Material Expressions of the Domestication Process. In: Martinsson-Wallin, H. (Ed.). Baltic Prehistoric Interactions and Transformations: The Neolithic to the Bronze Age. Pp. 39-6r. Visby: Gotland University Press.

Wehlin, J. 20I0. Approaching the Gotlandic Bronze Age from Sea: Future Possibilities from a Maritime Perspective. In: Martinsson-Wallin, H. (Ed.). Baltic Prehistoric Interactions and Transformations: The Neolithic to the Bronze Age. Pp. 89-I09. Visby: Gotland University Press.

Wehlin, J. 20I2. Vid stenskeppets akter: En nyfunnen dubbelgrav från Gotland. In: Alexandersson, K. et al. (Eds.). Forntid längs ostkusten 3: Blankaholmsseminariet air 201 I. Pp. I75-I99. Visby: Books on Demand.

Wehlin, J. 20I3. Östersjöns skeppssättningar: Monument och mötesplatser under yngre bronsålder. Diss. Göteborg: Göteborgs universitet.

Wehlin, J. 20I4. Tid, töisar och textil: Minnesbärande begravningar under brons- och äldre järnålder på Gotland. In: Alexandersson, H., Andreeff, A. \& Bünz, A. (Eds). Med hjärta och hjärna: En vänbok till professor Elisabeth Arwill-Nordbladh. Pp. 505-522. Göteborg: Göteborgs Universitet.

Wehlin, J. \& Schönbäck, B. 20I 2. En storgrav frän Gotlands bronsålder. Arkeologisk undersökning vid Simunde i Hörsne med Bara socken på Gotland 1957-58. Gotland University Press I3. Visby: Gotland University Press.

Werner, T. 2003. Stenskepp i Södermanland: Utbredning och datering. Fornvännen 98. Pp. 257-264.

Widholm, D. 2007. Stone ships: The Sea and the Heavenly Journey. Kalmar: Institutionen för humaniora och samhällskunskap, Högskolan i Kalmar.

\section{Internet resource}

FMIS. Riksantikvarieämbetets fornminnesinformation. [online] Available at: <www. fmis.raa.se> 